\title{
A study on contraceptive knowledge, attitudes and practices among women in the reproductive age group
}

\author{
Mansi Shukla ${ }^{1}$, Mallika Fonseca ${ }^{2}$, Prasad Deshmukh $^{1 *}$
}

\begin{abstract}
${ }^{1}$ Department of Obstetrics and Gynecology, LTM Medical College and Hospital, Sion, Mumbai, Maharashtra, India ${ }^{2}$ Department of Obstetrics and Gynecology, Grant Medical College and Sir JJ Group of Hospitals, Mumbai, Maharashtra, India
\end{abstract}

Received: 05 June 2017

Accepted: 29 June 2017

\author{
*Correspondence: \\ Dr. Prasad Deshmukh, \\ E-mail: drpydeshmukh@gmail.com
}

Copyright: () the author(s), publisher and licensee Medip Academy. This is an open-access article distributed under the terms of the Creative Commons Attribution Non-Commercial License, which permits unrestricted non-commercial use, distribution, and reproduction in any medium, provided the original work is properly cited.

\section{ABSTRACT}

Background: India, with one of the world's fastest growing populations, is a nation very much in need of contraceptive counselling. To assess the knowledge and attitude regarding family planning methods and contraceptive practices among women of reproductive age group.

Methods: A cross-sectional study was performed in which 547 women in the reproductive age group i.e., 15-45 years, attending a tertiary care hospital in Mumbai were interviewed with predesigned validated questionnaire. A total of 547 women were interviewed using a semi-structured questionnaire from January 2016 to December 2016. The proforma included details such as socio-demographic features, questions related to knowledge, attitude and practices (KAP) regarding contraceptive use.

Results: Out of 547 women interviewed, 498 (i.e. 91\%) had displayed an awareness of family planning methods (permanent/temporary). Out of these 498 women, about $78 \%$ had procured the information from family and friends. $13 \%$ got their information through mass media. Only $9 \%$ of women had been counselled in detail by health personnel about the various contraceptive options available. Out of 547 women interviewed, $342(62.5 \%)$ were using contraception. More than a third of these women (26.8\%), resort to barrier contraception as a contraceptive method of choice for spacing and to prevent an unwanted pregnancy. Only $17 \%$ women used OC Pills as a contraceptive method though $66 \%$ women knew about them. Though $59.4 \%$ of the women knew about IUCDs only $3.5 \%$ were actually using IUCD. Most of the women were in the younger age group of 21-30years $(62 \%)$ and already had one or two children.

Conclusions: Ignorance regarding use and side effects various contraceptive methods is the reason for inadequate practice of family planning methods. There should be emphasis on focused awareness programs, based on bridging the knowledge gaps among the women in reproductive age group.

Keywords: Attitude, Contraceptives, Knowledge, Practice

\section{INTRODUCTION}

India, with one of the world's fastest growing populations, is a nation very much in need of contraceptive counselling. ${ }^{1}$ Contraceptive advice is a vital component of good community health. An ideal contraceptive should suit an individual's personal, social, and medical needs. Socio-economic factors and education are some of the factors that play an important role in family planning acceptance. There are approximately 40 million women in India who would prefer to avoid becoming pregnant but are not practicing any form of contraception. ${ }^{2}$ In Indian scenario, females have no role in making of reproductive decisions. According to 
NFHS-3, around $30 \%$ of the fertility in India was unwanted, indicating a huge gap between the demand and supply of family planning measures and the unmet need for the country as a whole is about $13 \%$. The unmet need is high among married women aged $15-19$ years $(25 \%$ for spacing and $2 \%$ for limiting) and among those aged 20 24 years (15\% for spacing and over $6 \%$ for limiting). ${ }^{3-5}$ The present work was aimed to study of knowledge and awareness regarding contraception, study of contraceptive practices and study of socio-demographic parameters

\section{METHODS}

This is a facility-based cross-sectional study done in Department of Obstetrics and Gynecology at a tertiary care hospital in Mumbai. A total of 547 women in the reproductive age group attending OPD for various reasons were evaluated with a pre-designed questionnaire.

\section{Inclusion criteria}

Women eligible for contraception in the reproductive age group (15-49 years) who attended Gynecological OPD for varying complaints.

\section{Exclusion criteria}

Women in the reproductive age group not eligible for contraception.

After taking informed consent, women who fulfilled the inclusion criteria were interviewed. The questionnaire elicited information regarding their age, educational status, occupation, number of children, knowledge and source of contraceptive methods, practicing of family planning methods. The attitude of female towards contraception was assessed. Patients were Questioned to assess the knowledge about oral contraceptive pills, injectables, IUCD, condoms, tubectomy, vasectomy and also safe/ unsafe period of the menstrual cycle. The practice was defined by usage of contraceptive methods by either partner. Descriptive analysis conducted to obtain percentage. The results were represented as graphs and charts.

\section{RESULTS}

The socio-demographic features were given in Table 1.

Table 1: Age.

\begin{tabular}{|lll|}
\hline Age (years) & n & $\%$ \\
\hline$<20$ & 69 & 12.6 \\
\hline $21-25$ & 136 & 24.9 \\
\hline $26-30$ & 207 & 37.9 \\
\hline $31-35$ & 120 & 21.9 \\
\hline $36-40$ & 12 & 2.2 \\
\hline$>40$ & 3 & 0.5 \\
\hline
\end{tabular}

Table 2: Parity.

\begin{tabular}{|lll|}
\hline Parity & n & $\%$ \\
\hline Nullipara & 45 & 8.2 \\
\hline Primiparas & 134 & 24.5 \\
\hline Para 2 & 213 & 38.9 \\
\hline Para 3 & 84 & 15.4 \\
\hline Para 4 & 45 & 8 \\
\hline Grand multipara & 26 & 4.6 \\
\hline
\end{tabular}

Table 3: Years of marriage.

\begin{tabular}{|lll|}
\hline Years of marriage & n & $\%$ \\
\hline Unmarried (sexually active) & 12 & 2.2 \\
\hline$\leq 5$ years & 158 & 28.9 \\
\hline 6-10 years & 173 & 31.6 \\
\hline 11-15 years & 136 & 24.8 \\
\hline 16-20 years & 49 & 9 \\
\hline >20 years & 19 & 3.5 \\
\hline
\end{tabular}

Table 4: Educational status.

\begin{tabular}{|lll|}
\hline Educational status & n & $\%$ \\
\hline Illiterate & 108 & 19.7 \\
\hline Primary school $\left(1^{\text {st }}\right.$ to $4^{\text {th }}$ std) & 233 & 42.6 \\
\hline Secondary (till $10^{\text {th }}$ std) & 81 & 14.8 \\
\hline Junior college & 68 & 12.4 \\
\hline Graduate and above & 57 & 10.5 \\
\hline
\end{tabular}

Out of 547 women in the study, $207(38 \%)$ were in the age group of $26-30$ years. 45 women $(8.2 \%)$ had no children. $134(24.5 \%)$ were primipara's and the rest were multiparas. $158(28.9 \%)$ women were married for less than 5 years. As many as 108 women (19.7\%) were illiterate.

Table 5: Knowledge.

\begin{tabular}{|lll|}
\hline Knowledge & n & $\%$ \\
\hline Not aware of contraceptives & 49 & 9 \\
\hline Tubal ligation & 498 & 91 \\
\hline Vasectomy & 153 & 28 \\
\hline IUCD & 325 & 59.4 \\
\hline Barrier & 407 & 74.4 \\
\hline OCP & 363 & 66.3 \\
\hline Injectable contraception & 24 & 4.3 \\
\hline Safe period & 17 & 3.1 \\
\hline
\end{tabular}

Out of the 547 women $498(91 \%)$ were aware about the concept of contraception and knew about at least one method of contraception.

Out of these, all the females were aware of Tubal Ligation while only $28 \%$ (153 women) were aware about Vasectomy. 407 (74\%) were aware of barrier methods (male condoms), $363(66 \%)$ knew about oral contraceptive pills and only $325(59.4 \%)$ knew about IUCD. $4.3 \%$ had some information about injectable 
contraceptives and $17(3.1 \%)$ women were aware of the safe period of menstrual cycle.

Table 6: Source of information.

\begin{tabular}{|lll|}
\hline Source of awareness & n & $\%$ \\
\hline Media & 65 & 13 \\
\hline Social circle & 389 & 78.1 \\
\hline Health personnel & 44 & 8.9 \\
\hline
\end{tabular}

The source of knowledge was mostly through social circle in 389 women $(78.1 \%)$, through media in 65 women $(13 \%)$ and only 44 women $(8.9 \%)$ got awareness through health personnel. 49 women $(9 \%)$ did not know about any type of contraception (either permanent or temporary). $37 \%$ of the women were aware of more than one method of contraception.

Table 7: Contraceptive method being used.

\begin{tabular}{|c|c|c|}
\hline Type of contraceptive used & n & $\%$ \\
\hline Male condom & 147 & 26.8 \\
\hline $\mathrm{OCP}$ & 92 & 16.8 \\
\hline IUCD & 19 & 3.5 \\
\hline Safe period & 84 & 15.5 \\
\hline None & 205 & 37.4 \\
\hline
\end{tabular}

Table 8: Reason for using contraceptive.

\begin{tabular}{|lll|}
\hline Reasons for using contraceptive & n & $\%$ \\
\hline Completed family & 77 & 22.5 \\
\hline Spacing & 184 & 53.8 \\
\hline Financial problems & 29 & 8.5 \\
\hline Lack of family support & 37 & 10.8 \\
\hline Advised by doctor for medical reason & 15 & 4.4 \\
\hline
\end{tabular}

Of the 547 women interviewed and of the 498 women with a knowledge of contraceptives, only 342 women $(62.5 \%)$ were using temporary contraceptives of which, male condoms $147(26.8 \%)$ were the major method used. 363 women $(66.3 \%)$ were aware of oral contraceptive pills but only 92 women $(16.8 \%)$ were actually on OC pills. Similarly, though 153 women $(26.8 \%)$ knew about IUCD, only 19 women $(3.5 \%)$ had actually inserted an IUCD for contraception.

Table 9: Reason for not using contraception.

\begin{tabular}{|lll|}
\hline Reasons for not using contraceptive & n & $\%$ \\
\hline Lack of/ inadequate knowledge & 112 & 54.6 \\
\hline Want more children & 32 & 15.6 \\
\hline Want Male child & 17 & 8.3 \\
\hline Partner Opposition & 9 & 4.4 \\
\hline Religious Reasons & 18 & 8.8 \\
\hline Fear of Side Effects & 17 & 8.3 \\
\hline
\end{tabular}

Most of the women (53.8\%) were using contraceptives for spacing. $22.5 \%$ used contraception because they had completed their family.
Out of 205 women who are not using contraception 112 women $(54.6 \%)$ did not having knowledge about the various methods of contraception. Other reasons for not practising contraception were cited as desire for male child, religious reasons, fear of side effects, fear of family opposition etc.

Table 10: Attitude.

\begin{tabular}{|lll|}
\hline Attitude & n & $\%$ \\
\hline Approve of contraceptive use & 342 & 62.5 \\
\hline Willing to try immediately & 67 & 12.3 \\
\hline Willing to try later & 59 & 10.8 \\
\hline Neutral & 23 & 4.2 \\
\hline Apprehensive & 11 & 2 \\
\hline Disapprove of contraceptive use & 45 & 8.2 \\
\hline
\end{tabular}

Out of 547 women interviewed, 468 approved of the use of contraceptive methods.

Of these $342(62.5 \%)$ had positive attitude towards practice of family planning methods. 23 (4.2\%) were neutral in their response. 56 women $(10 \%)$ had negative attitude towards contraception in spite of counselling.

\section{DISCUSSION}

In present study, most of the women were from the age group of 21-30 years i.e. younger patients. Most of these patients already had one or two children. Evidence from a number of small studies in various parts of the country indicate that inadequate knowledge of contraceptive methods is a reason for not accepting family planning.

In present study $91 \%$ of women were aware of one or more methods of contraception. In two other, Indian studies the awareness rate was $82.8 \%$ and $100 \% .^{6,7}$ But in practice only $62.5 \%$ of women are using contraception methods. $37.5 \%$ women are not using them due to lack of knowledge or other misconceptions. Other Indian studies showed similar results $52 \%, 55 \%, 46 \%$ of non-users. ${ }^{7,8}$ $17 \%$ expressed concerns about the side effects as the reason for not using them.

Emphasis should be made on communication and thorough counselling to the couples about availability, use and side effects of contraceptive methods. The major source of knowledge is social circle $(78 \%)$ and media in $13 \%$. Similar results were found in other studies, 42 and $15 \%$ respectively. ${ }^{7}$ Mass media plays an important role in promotion and acceptability of contraception. ${ }^{9}$

The need to advertise through media is to be enhanced as $43 \%$ of the women interviewed were illiterate. The health personnel, especially MPHW (F) and ASHA workers should discuss the need of contraception, especially spacing methods to bridge the gap between knowledge and practice of contraception. There is no doubt that we can reduce maternal mortality and morbidity by creating more contraceptive awareness and spacing out 
pregnancies. Information regarding temporary contraception for teenagers should be given at schools and colleges to prevent unwanted pregnancies and MTPs.

Promoting injectable contraceptives and PPIUCD insertion at Hospitals also play a vital role in improving maternal health. Male sterisation awareness and acceptance needs to be improved.

\section{CONCLUSION}

Family planning and correct choice of contraceptives is very essential. Health care providers have to ensure the spread of information regarding all the modes of contraception available these days. Motivation of the males towards the usage of male contraceptive measures (both temporary and permanent) is necessary. Permanent contraception should be encouraged in both males and females to ensure better maternal and child health.

Funding: No funding sources

Conflict of interest: None declared

Ethical approval: The study was approved by the Institutional Ethics Committee

\section{REFERENCES}

1. Hammad AQ, Hashmi A, Syed AR, Jamil AS, Aslam G. Contraceptive methods and factors associated with modern contraceptive in use. J Fam Reprod Health. 2010;4:41-6.

2. Al-Mualm YK. Knowledge, attitude and practice of husbands towards modern family planning in Yemen. 2007.
3. Weldegerima B, Denekew A. Women's knowledge, preferences, and practices of modern contraceptive methods in Woreta, Ethiopia. Res Social Adm Pharm. 2008;4:302-7.

4. International Planned Parenthood Federation: directory of hormonal contraceptives medical and service delivery guidelines. 3rd ed. 2004. Available at

http://www.ippf.org/sites/default/files/ippf_medical_ and_service_delivery_guidelines_english.pdf

5. Mahawar P, Anand S, Raghunath D, Dixit S. Contraceptive knowledge, attitude and practices in mothers of infant: a cross-sectional study. Natl J Comm Med. 2011;2:1-174.

6. Rao PD, Babu MS. Knowledge and use of contraception among Racha Koyas of Andhra Pradesh. Anthropologist. 2005;7:115-9.

7. Renjhen P, Gupta SD, Barua A, Jaju S, Khati B. A study of knowledge, attitude and practice of family planning among the women of reproductive age group in Sikkim. J Obstet Gynecol India. 2008;58:63-7.

8. USAID. Contraceptive Trends in Developing Countries: DHS Comparative Report 16. Maryland; 2007

9. World Health Organization U, UNFPA, World Bank (2012) Trends in maternal mortality: 1990 to 2010 World Health Organization Geneva.

Cite this article as: Shukla M, Fonseca M, Deshmukh P. A study on contraceptive knowledge, attitudes and practices among women in the reproductive age group. Int J Reprod Contracept Obstet Gynecol 2017;6:3560-3. 